\title{
KELAYAKAN USAHA BUDIDAYA IKAN BANDENG DI SAWAH TAMBAK (Studi Kasus pada Kelompok Tani 'Makin Makmur" Di Desa Deket Wetan Kecamatan Deket Kabupaten Lamongan)
}

\author{
THE FEASIBILITY OF MILKFISH CULTIVATION IN A PADDY POND \\ (Case Study on Farmer Group 'Makin Makmur' in Deket Wetan Village, \\ In Deket District, Lamongan Regency)
}

\author{
Wachidatus Sa'adah \\ Fakultas Perikanan Universitas Islam Lamongan \\ Email: wachidaafandi@gmail.com \\ (Diterima 29-06-2020; Disetujui 25-07-2020)
}

\begin{abstract}
ABSTRAK
Daerah Jawa Timur yang mempunyai potensi sumber daya perikanan yang cukup besar untuk perikanan budidaya salah satunya terdapat di Kabupaten Lamongan. Kabupaten Lamongan merupakan sentra perikanan budidaya dengan lahan sawah tambak seluas $23.774,73$ ha yang tersebar di wilayah tengah dan produk utama serta andalannya adalah ikan bandeng. Tujuan dilakukan penelitian ini untuk mengetahui kelayakan usaha budidaya ikan bandeng di sawah tambak di desa Deket Wetan Kecamatan Deket Kabupaten Lamongan. Metode yang digunakan dalam penelitian ini adalah metode kuantitatif, dan pengambilan sampelnya dilakukan secara purposive sampling pada salah satu kelompok tani pembudidaya ikan bandeng di sawah tambak yang bernama "Makin Makmur". Hasil penelitian menunjukkan bahwa R/C sebesar 1,53 yang menunjukkan bahwa usaha ini menguntungkan dan layak untuk diusahakan, BEP penerimaan Rp 32.722.087, ini artinya bahwa harus dapat mencapai penjualan Rp32.722.087 agar mencapai BEP dan BEP volume produksi $1.924 \mathrm{~kg}$, dapat dijelaskan bahwa harus dapat memproduksi ikan bandeng sebanyak $1.924 \mathrm{~kg}$ untuk mencapai BEP.
\end{abstract}

Kata kunci: ikan bandeng, sawah tambak, kelayakan usaha

\begin{abstract}
East Java, which has a large enough potential of fisheries resources for aquaculture, one of which is in Lamongan Regency. Lamongan Regency is a center of aquaculture with a pond rice field area of 23,774.73 Ha which is spread in the middle area and the main product and its mainstay is milkfish. The purpose of this study was to determine the feasibility of milkfish fish farming in ponds in the village of Deket Wetan, Deket District, Lamongan Regency. The method used in this study is a quantitative method, and the sample collection was carried out using a purposive sample in one of the milkfish farmer farmer groups in a rice field named "Makin Makmur". The results showed that the $R / C$ was 1.53 , if the $R / C>1$, then this business was profitable and feasible to be undertaken, the received BEP was Rp32,722,087, this meant that it had to be able to reach sales of $R p 32,722,087$ in order to reach the BEP and BEP production volume obtained 1,924 $\mathrm{kg}$, it can be explained that it must be able to produce as much as 1,924 kg of milkfish to reach BEP.
\end{abstract}

Keywords: milkfish, paddy pond, business feasibility

\section{PENDAHULUAN}

Pengembangan pertanian termasuk didalamnya sub sektor perikanan sampai saat ini yakni pemenuhan produksi perikanan baik untuk kebutuhan ekspor maupun konsumsi didominasi oleh hasil 
budidaya juga telah mampu menunjukkan dukungan positif terhadap peningkatan ekspor non migas nasional. Salah satu daerah di Jawa Timur yang mempunyai potensi sumber daya perikanan yang cukup besar yang salah satunya yaitu perikanan budidaya di Kabupaten Lamongan. Kabupaten Lamongan merupakan sentra perikanan budidaya dengan sawah tambak seluas $23.774,73$ ha yang tersebar di wilayah tengah dan produk utama serta andalannya adalah ikan bandeng (Pemerintah Kabupaten Lamongan, 2019).

Menurut Ghufran (2015), bandeng (Chanos chanos) merupakan ikan laut yang paling banyak dibudidayakan di Indonesia, terutama di tambak. Provinsi Jawa Timur dan Sulawesi Selatan merupakan sentra bandeng di Indonesia. Bandeng adalah ikan yang toleran terhadap salinitas atau kadar garam. Bandeng hidup dan tumbuh pada kisaran salinitas $\quad 0-60 \quad$ ppt. Bandeng memungkinkan dipelihara pada kepadatan tinggi karena dapat beradaptasi dengan pakan buatan, aktif bergerak sehingga menambah kelarutan oksigen.

Berdasarkan latar belakang di atas, maka tujuan dari penelitian ini adalah untuk mengetahui kelayakan usaha budidaya ikan bandeng di sawah tambak di desa Deket Wetan Kecamatan Deket Kabupaten Lamongan

\section{METODE PENELITIAN}

Penelitian yang dilakukan adalah penelitian deskriptif. Menurut Juliansyah (2011), penelitian deskriptif adalah penelitian yang berusaha mendeskripsikan suatu gejala, peristiwa, kejadian yang terjadi saat sekarang. Sedangkan metode yang digunakan adalah metode kuantitatif yaitu metode menyangkut pengetahuan teknis tentang pengukuran, desain, dan berbagai metode kuantitatif dengan penekanan atas teori-teori formal tentang fenomena alam.

Penelitian ini dilaksanakan di Desa Deket Wetan Kecamatan Deket Kabupaten Lamongan.

Pengambilan sampel dilakukan secara purposive sampling. Menurut Suharsimi (2010), purposive sampling ini dilakukan dengan cara mengambil subjek bukan didasarkan atas strata, acak atau daerah tetapi didasarkan atas adanya tujuan tertentu. Subjek yang diambil merupakan subjek yang paling banyak mengandung ciri-ciri yang terdapat pada populasi. Berdasarkan pengertian tersebut, maka pemilihan sampelnya adalah salah satu dari kelompok tani pembudidaya ikan bandeng di sawah 
tambak yang bernama "Makin Makmur". Kelompok tani ini beranggotakan 15 orang.

Teknik pengumpulan data dalam penelitian ini bersumber dari data primer dan data sekunder. Menurut Aziz (2012), data primer adalah data yang diperoleh sendiri oleh perorangan/organisasi langsung melalui objeknya. Sedangkan data sekunder adalah data yang diperoleh dalam bentuk yang sudah jadi berupa publikasi.

Metode analisis yang digunakan dalam penelitian ini adalah analisis kelayakan usaha. Untuk menganalisisnya ada beberapa data yang perlu diketahui yaitu data tentang penerimaan, biaya dan pendapatan petani (Soekartawi, 2006).

Penerimaan adalah perkalian antara produksi yang diperoleh (Y) dengan harga jual (Py), dan dapat ditulis sebagai berikut:

$$
\mathrm{TR}=\mathrm{Y} \text {. Py }
$$

Biaya diklasifikasikan menjadi dua, yaitu biaya tetap (fixed cost) dan biaya tidak tetap (variable cost). Biaya tetap adalah biaya yang relatif tetap jumlahnya, dan terus dikeluarkan meskipun produksi yang diperoleh banyak atau sedikit. Biaya tidak tetap adalah biaya yang besar kecilnya dipengaruhi oleh produksi yang diperoleh. Biaya total (total cost) adalah jumlah dari biaya tetap dan biaya tidak tetap, dan dapat ditulis sebagai berikut:

$$
\mathrm{TC}=\mathrm{FC}+\mathrm{VC}
$$

Pendapatan adalah selisih antara penerimaan dan semua biaya, dan dapat ditulis sebagai berikut:

$$
\mathrm{Pd}=\mathrm{TR}-\mathrm{TC}
$$

Menurut Soekartawi (2006), kelayakan usaha bisa diuji dengan analisis $\mathrm{R} / \mathrm{C}$. R/C adalah perbandingan antara penerimaan dan biaya, dan dapat ditulis sebagai berikut:

$$
\begin{aligned}
& \mathrm{R} / \mathrm{C}=\mathrm{a} \\
& \mathrm{R}=\mathrm{Py} . \mathrm{Y} \\
& \mathrm{C}=\mathrm{FC}+\mathrm{VC} \\
& \mathrm{a}=\{(\mathrm{Py} . \mathrm{Y}) /(\mathrm{FC}+\mathrm{VC})\}
\end{aligned}
$$

Secara teoritis:

$\mathrm{R} / \mathrm{C}=1$, artinya tidak untung dan tidak rugi

$\mathrm{R} / \mathrm{C}>1$, artinya menguntungkan

$\mathrm{R} / \mathrm{C}<1$, artinya rugi

Analisis Break Even Point (BEP) juga penting untuk menunjukkan keadaan dimana suatu usaha tidak memperoleh keuntungan dan tidak mengalami kerugian (Mimit, 2011). Cara menghitungnya ada 2 macam:

1. BEP atas dasar penerimaan, dapat ditulis sebagai berikut:

$$
\mathrm{BEP}=\frac{\mathrm{FC}}{1-\frac{\mathrm{VC}}{\mathrm{TR}}}
$$


2. BEP atas dasar volume produksi, dapat ditulis sebagai berikut:

$$
\mathrm{BEP}=\frac{\text { BEP penerimaan }}{\text { Harga Satuan }}
$$

\section{HASIL DAN PEMBAHASAN}

\section{A. Keadaan Umum Daerah}

Desa Deket Wetan adalah desa yang ditempati sebagai pusat pemerintahan Kecamatan Deket, Kabupaten Lamongan. Adapun batasbatas wilayah Desa Deket Wetan adalah sebagai berikut:

Sebelah Utara : Desa Rejosari

Sebelah Selatan: Desa Simbatan

Sebelah Timur : Desa Pandan Pancur

Sebelah Barat : Desa Deket Kulon

\section{B. Profil Kelompok Tani "Makin Makmur"}

\section{a. Latar Belakang}

Menurut Kementerian Kelautan dan Perikanan (2018), kelompok tani "Makin Makmur" di Desa Deket Wetan Kecamatan Deket terbentuk pada tanggal 5 Maret 2018, beranggotakan pembudidaya ikan dan udang di sawah tambak dengan jumlah anggota 15 orang. Lokasi lahan budidaya terletak dalam satu hamparan kawasan sawah tambak, yang saling berdekatan. Sehingga setiap hari saling bertemu dan berkomunikasi tentang budidaya ikan/udang di sawah tambak mereka.
Budidaya ikan dan udang di sawah tambak dilakukan secara polikultur dengan sistem tradisional, sehingga masih sangat tergantung alam. Pada saat ini komoditas utamanya salah satunya adalah ikan bandeng. Berbagai kendala budidaya akan mulai dirasakan pada saat musim hujan dengan perubahan suhu harian yang ekstrim (terjadi angin dasar), sehingga ikan Bandeng akan mengalami kelambatan pertumbuhan.

Untuk mendapatkan solusi pemecahan masalah budidaya tersebut, beberapa pembudidaya bersepakat membentuk kelompok, untuk dapat saling berdiskusi mendapat solusi/inovasi terbaru dalam budidaya Ikan di sawah tambak. Bertempat di Balai Desa Deket Wetan, dengan dibantu fasilitasi pemerintah desa (kepala desa) dan penyuluh perikanan, sehingga pada tanggal 5 Maret 2018, Kelompok Tani "Makin Makmur" terbentuk.

\section{b. Tujuan}

Tujuan dibentuknya Kelompok Tani "Makin Makmur" ini adalah:

1. Sebagai wadah pemecahan masalah dan sumber informasi terbaru teknologi perikanan; 
2. Meningkatkan kemampuan budidaya ikan sesuai Kriteria Cara Budidaya Ikan yang Baik (CBIB);

3. Meningkatkan produksi dan produktifitas ikan dan udang di sawah tambak;

4. Meningkatkan pendapatan dan kesejahteraan anggota kelompok.

\section{c. Visi dan Misi}

1. Visi

Menjadi kelompok perikanan yang maju, mandiri dan berdaya saing

2. Misi

Adapun misi dari kelompok tani ini adalah sebagai berikut:

1. Peningkatan kemampuan Sumber Daya Manusia dan inventaris kelompok dalam penerapan teknologi budidaya ikan sesuai Kriteria Cara Budidaya Ikan yang Baik (CBIB);

2. Peningkatan produksi dan produkstifitas budidaya ikan di sawah tambak;

3. Peningkatan pendapatan dan kesejahteraan anggota kelompok;

4. Penguatan kemandirian permodalan kelompok dan administrasi kelompok.

\section{d. Struktur Organisasi}

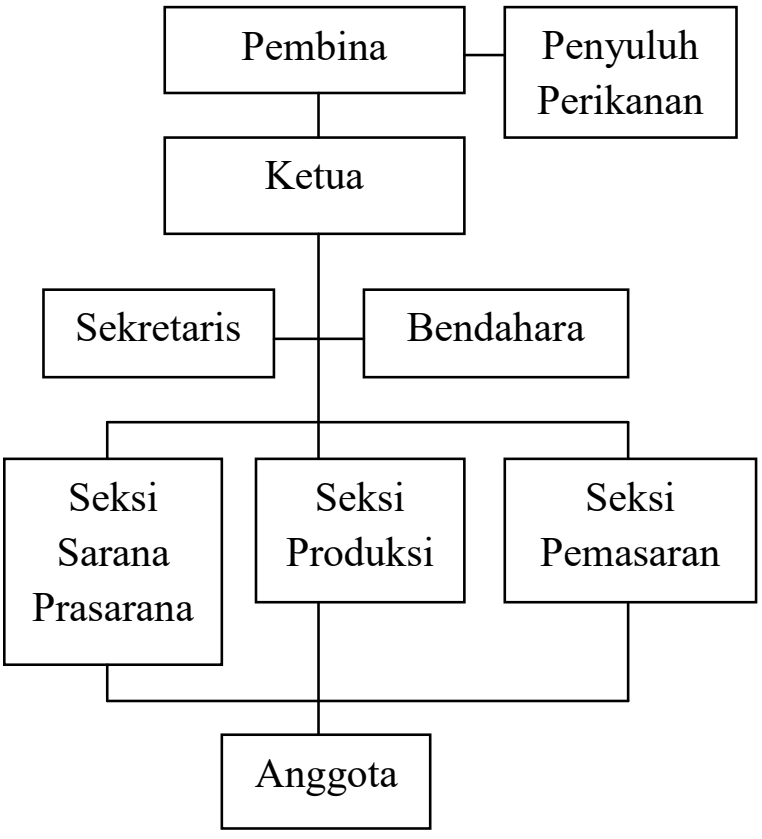

Gambar 1. Struktur Organisasi Kelompok Tani "Makin Makmur"

\section{e. Deskripsi Usaha Budidaya Ikan Bandeng}

\section{Luas Lahan}

Jenis usaha kelompok tani "Makin Makmur" adalah budidaya perikanan. Komoditas yang diusahakan adalah ikan bandeng. Sistem budidaya yang diterapkan adalah sistem tradisional. Lahan yang diusahakan berupa sawah tambak dengan luas areal sebesar 12 ha. Untuk mengetahui sebaran lahan yang diusahakan dapat dilihat pada Tabel 1. 
Tabel 1. Luas Lahan Kelompok Tani “Makin

\begin{tabular}{clc}
\multicolumn{3}{c}{ Makmur" } \\
\hline No & Nama Anggota & Luas Lahan (ha) \\
\hline 1 & Arif & 1,5 \\
2 & Slamet & 1 \\
3 & Santoso & 1 \\
4 & Pujiyanto & 0,5 \\
5 & Saean & 1 \\
6 & Mamsur & 0,5 \\
7 & Hadi & 1 \\
8 & Mat Rawi & 0,5 \\
9 & Nur Abidin & 1 \\
10 & Yaselan & 0,5 \\
11 & Subhan & 0,5 \\
12 & Suladi & 1 \\
13 & Masruri & 1 \\
14 & Ali & 0,5 \\
15 & M. Ali & 0,5 \\
\hline Data & Primer, 2020
\end{tabular}

\section{Budidaya Ikan Bandeng}

Bandeng adalah ikan yang toleran terhadap salinitas atau kadar garam. Bandeng hidup dan tumbuh pada kisaran salinitas $\quad 0-60 \quad$ ppt. Bandeng memungkinkan dipelihara pada kepadatan tinggi karena dapat beradaptasi dengan pakan buatan, aktif bergerak sehingga menambah kelarutan oksigen.

Adapun langkah-langkah budidaya ikan bandeng meliputi persiapan lahan, pemeliharaan, dan panen.

a) Persiapan Lahan

Pada tahap persiapan lahan seperti pengeringan, pengolahan tanah, pengapuran, dan pemupukan (Ghufran, 2015). Pengeringan tambak berguna untuk memperbaiki kondisi dasar tambak, kemudian pengolahan tanah dengan cara mengangkat lumpur agar tidak menjadi media berkembangnya penyakit, kemudian tanah dicangkul dan dibalik setelah itu diratakan kembali, dan dilakukan pengapuran dengan kapur dolomit. Tujuan pengapuran untuk menaikkan dan menetralisisr $\mathrm{pH}$ tanah dasar tambak karena kapur memberikan reaksi basa (Khairul, 2008). Selanjutnya pemupukan dengan menggunakan pupuk urea dan TSP 36. Setelah itu tambak diisi air setinggi $40 \mathrm{~cm}$ dan bisa dilakukan penebaran benih, dan aklimatisasi benih dan diteruskan dengan menambah ketinggian air secara bertahap hingga mencapai $1 \mathrm{~m}$.

b) Pemeliharaan

Selama pemeliharaan ikan membutuhkan pakan, baik pakan alami maupun pakan buatan. Untuk pakan buatan menggunakan pakan lestari. Disamping itu, pertumbuhan ikan juga harus dipantau dengan sampling setiap dua minggu sekali menggunakan jaring. Lama pemeliharaan ikan bandeng dalam penelitian ini setiap siklus memerlukan waktu 6 bulan yang terbagi atas dua siklus yang masing-masing siklusnya makan waktu 3 bulan. Untuk bulan berikutnya digunakan untuk produksi padi. 


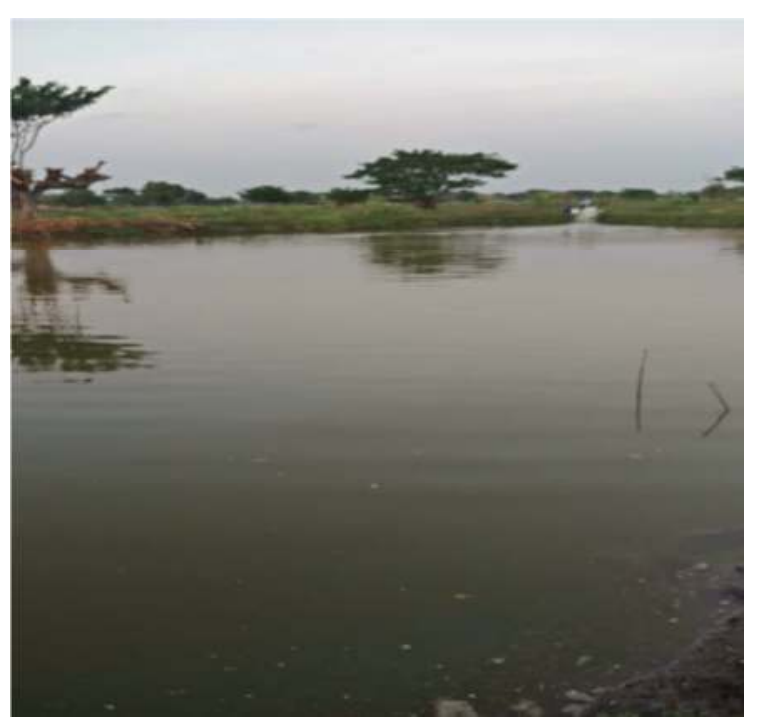

Gambar 2. Tambak dalam Pemeliharaan

c) Pemanenan

Pemanenan adalah kegiatan terakhir dari budidaya, pemanenan dilakukan jika ukuran ikan bandeng sudah memenuhi target ukuran permintaan pasar. Semakin besar ukurannya semakin mahal harganya. Total produksi ikan bandeng dapat dilihat pada Tabel 2.

Tabel 2. Produksi Ikan Bandeng per Tahun

\begin{tabular}{lccc}
\hline $\begin{array}{c}\text { Kelompok } \\
\text { Tani }\end{array}$ & $\begin{array}{c}\text { Luas } \\
\text { Lahan (ha) }\end{array}$ & $\begin{array}{c}\text { Produksi } \\
(\mathrm{kg})\end{array}$ & $\begin{array}{c}\text { Kete- } \\
\text { rangan }\end{array}$ \\
\hline $\begin{array}{l}\text { Makin } \\
\text { Makmur }\end{array}$ & 12 & 7.200 & 2 siklus \\
\hline
\end{tabular}

Sumber: Data Primer, 2020

Tabel 2 menunjukkan bahwa produksi ikan bandeng kelompok tani "Makin Makmur" per tahun (2 siklus) adalah $7.200 \mathrm{~kg}$.

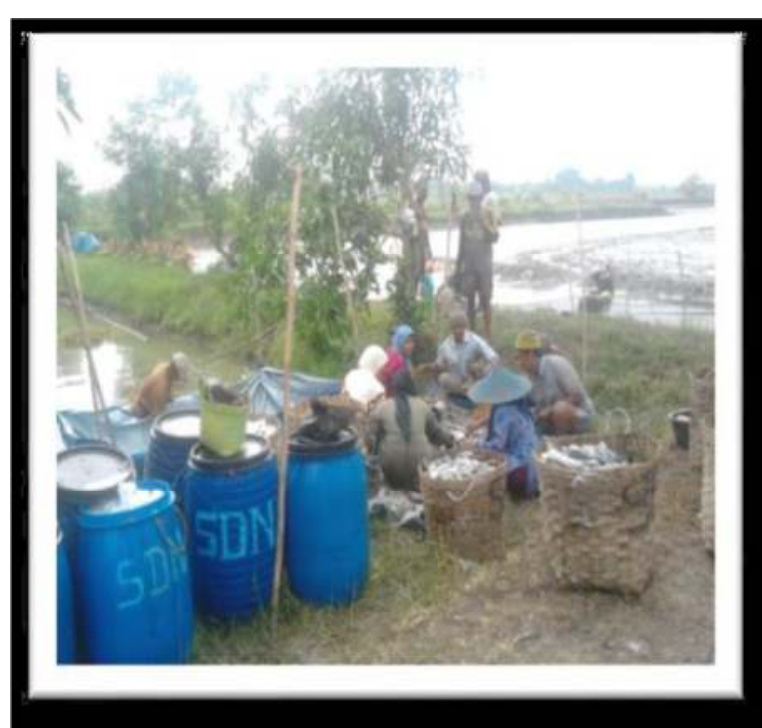

Gambar 3. Kegiatan Panen Ikan Bandeng

\section{f. Kelayakan Usaha}

\section{Biaya}

Setiap kegiatan usaha selalu membutuhkan biaya, dan biaya yang dikeluarkan untuk kegiatan budidaya mulai dari persiapan sampai ada 2 yaitu biaya tetap (FC) dan biaya tidak tetap (VC). Biaya tetap yang dikeluarkan dalam kegiatan usaha ini berupa pajak tanah, sewa peralatan, dan penyusutan alat. Sedangkan biaya tidak tetap berupa pembelian benih, kapur, pupuk, pakan, bbm, dan upah tenaga kerja. Jika sudah diketahui jumlah dari kedua biaya tersebut maka dapat dicari total biayanya. Masing-masing biaya dapat dilihat pada Tabel 3. 
Tabel 3. Biaya Tetap Budidaya Ikan Bandeng Per Tahun

\begin{tabular}{lc}
\hline \multicolumn{1}{c}{ Uraian Biaya } & $\begin{array}{c}\text { Biaya Tetap } \\
(\mathrm{Rp})\end{array}$ \\
\hline $\begin{array}{l}\text { Pajak tanah, } \\
\text { sewa peralatan, dan penyusutan } \\
\text { alat }\end{array}$ & 15.432 .660 \\
\hline
\end{tabular}

Sumber: Data Primer, 2020

Tabel 4. Biaya Tidak Tetap Budidaya Ikan Bandeng per Tahun

\begin{tabular}{lc}
\hline \multicolumn{1}{c}{ Uraian Biaya } & $\begin{array}{c}\text { Biaya Tidak Tetap } \\
(\mathrm{Rp})\end{array}$ \\
\hline $\begin{array}{l}\text { Benih, kapur, pupuk, } \\
\text { pakan, bbm, dan upah } \\
\text { tenaga kerja }\end{array}$ & 64.672 .706 \\
\hline Sumber: Data Primer, 2020 &
\end{tabular}

Tabel 5. Biaya Total Budidaya Ikan Bandeng per Tahun

\begin{tabular}{ccc}
\hline $\begin{array}{c}\text { Biaya } \\
\text { Tetap (Rp) }\end{array}$ & $\begin{array}{c}\text { Biaya Tidak } \\
\text { Tetap (Rp) }\end{array}$ & $\begin{array}{c}\text { BiayaTotal } \\
(\mathrm{Rp})\end{array}$ \\
\hline 15.432 .660 & 64.672 .706 & 80.105 .366 \\
\hline
\end{tabular}

Sumber: Data Primer Terolah, 2020

Tabel di atas menunjukkan bahwa jumlah biaya tetap yang dikeluarkan oleh kelompok tani 'Makin Makmur" per tahun adalah $\mathrm{Rp}$ 15.432.660, biaya tidak tetap sebesar Rp 64.672.706, dan biaya totalnya sebesar Rp 80.105.366.

\section{Penerimaan}

Bahwasanya penerimaan bisa dihitung manakala telah diketahui jumlah keseluruhan produksi kemudian dikalikan dengan harga jual. Untuk perolehan penerimaan dapat dilihat pada Tabel 6 .

Tabel 6. Penerimaan Budidaya Ikan Bandeng per Tahun

\begin{tabular}{ccc}
\hline $\begin{array}{c}\text { Produksi } \\
(\mathrm{Kg})\end{array}$ & $\begin{array}{c}\text { Harga } \\
(\mathrm{Rp} / \mathrm{Kg})\end{array}$ & $\begin{array}{c}\text { Penerimaan } \\
(\mathrm{Rp})\end{array}$ \\
\hline 7.200 & 17.000 & 122.400 .000 \\
\hline
\end{tabular}

Sumber: Data Primer Terolah, 2020
Tabel 6 menunjukkan bahwa jumlah penerimaan yang diperoleh oleh kelompok tani "Makin Makmur" adalah Rp 122.400.000.

\section{Pendapatan}

Pendapatan atau keuntungan usaha pada kegiatan usaha sebaiknya bernilai positif. Oleh karena itu, jumlah TR harus lebih besar dari TC. Untuk perolehan pendapatan dapat dilihat pada Tabel 7 .

Tabel 7. Pendapatan Budidaya Ikan Bandeng Per Tahun

\begin{tabular}{ccc}
\hline $\begin{array}{c}\text { Penerimaan } \\
(\mathrm{Rp})\end{array}$ & $\begin{array}{c}\text { Biaya Total } \\
(\mathrm{Rp})\end{array}$ & $\begin{array}{c}\text { Jumlah Pendapatan } \\
(\mathrm{Rp})\end{array}$ \\
\hline 122.400 .000 & 80.105 .366 & 42.294 .634 \\
\hline
\end{tabular}

Sumber: Data Primer Terolah, 2020

Dari tabel tersebut menunjukkan bahwa pendapatan yang diperoleh oleh kelompok tani "Makin Makmur" adalah Rp42.294.634.

\section{4. $\mathrm{R} / \mathrm{C}$}

Parameter kelayakan usaha bisa dilihat dari perolehan nilai $\mathrm{R} / \mathrm{C}$, semakin besar hasilnya semakin layak untuk diusahakan. Untuk perolehan nilai $\mathrm{R} / \mathrm{C}$ bisa dilihat pada Tabel 8 .

Tabel 8. Nilai R/C Budidaya Ikan Bandeng per Tahun

Penerimaan $(\mathrm{Rp}) \quad$ Biaya Total $(\mathrm{Rp}) \quad \mathrm{R} / \mathrm{C}$

$\begin{array}{lll}122.400 .000 & 80.105 .366 & 1,53\end{array}$

Sumber: Data Primer Terolah, 2020

Tabel 8 menunjukkan bahwa nilai $\mathrm{R} / \mathrm{C}$ yang diperoleh oleh kelompok tani "Makin Makmur" lebih dari 1 yaitu 1,53, artinya bahwa setiap rupiah biaya yang 
dikeluarkan dalam usaha ini akan memperoleh penerimaan sebesar Rp 1,53, dan usaha ini layak untuk diusahakan, sejalan dengan penelitian Wachidatus (2018), bahwa R/C adalah 1,15, dari uraian tersebut dapat diartikan bahwa usaha pengasapan ikan tawes ini menguntungkan dan layak untuk dikembangkan.

\section{BEP (Break Even Point)}

BEP untuk mengetahui bahwa kondisi usaha pada posisi impas yaitu tidak untung dan tidak rugi, yang artinya bahwa perolehan penerimaan sama dengan biaya yang dikeluarkan. Hasil BEP penerimaan dan BEP volume produksi dari kegiatan usaha budidaya ikan bandeng dapat dilihat pada Tabel 9.

Tabel 9. Nilai BEP Budidaya Ikan Bandeng Per Tahun

\begin{tabular}{cc}
\hline $\begin{array}{c}\text { BEP Penerimaan } \\
(\mathrm{Rp})\end{array}$ & $\begin{array}{c}\text { BEP Volume Produksi } \\
(\mathrm{Kg})\end{array}$ \\
\hline 32.722 .087 & 1.924 \\
\hline
\end{tabular}

Sumber: Data Primer Terolah, 2020

Tabel 9 menunjukkan bahwa nilai BEP penerimaan adalah Rp32.722.087 dan nilai BEP volume produksi adalah $1.924 \mathrm{~kg}$.

\section{KESIMPULAN DAN SARAN}

Berdasarkan hasil penelitian dan pembahasan, maka dapat ditarik kesimpulan bahwa parameter dari kelayakan usaha:

1. R/C dari budidaya ikan bandeng kelompok tani "Makin Makmur" sebesar $\quad 1,53$. Jika R/C $>1$, maka usaha ini menguntungkan dan layak untuk diusahakan.

2. a. BEP penerimaan diperoleh Rp32.722.087, ini artinya bahwa kelompok tani "Makin Makmur" harus dapat mencapai penjualan Rp32.722.087 agar mencapai BEP.

b. BEP volume produksi diperoleh $1.924 \mathrm{~kg}$, dapat dijelaskan bahwa kelompok tani "Makin Makmur" harus dapat memproduksi ikan bandeng sebanyak $1.924 \mathrm{~kg}$ untuk mencapai BEP.

\section{DAFTAR PUSTAKA}

Amri, K dan Kanna, I. 2008. Budidaya Udang Vanname Secara Intensif, Semi Intensif, dan Tradisional. Jakarta : Gramedia Pustaka Utama.

Arikunto, S. 2010. Prosedur Penelitian Suatu Pendekatan Praktik. Jakarta : Rineka Cipta.

Firdaus, M. A. 2012. Metode Penelitian. Tangerang Selatan : Jelajah Nusa.

K. M. Ghufran, H. K. 2015. Akuakultur Intensif dan Super Intensif Produksi Tinggi Dalam Waktu Singkat. Jakarta : Rineka Cipta.

Kementerian Kelautan Dan Perikanan, 2018.

Profil Kelompok Perikanan. 
Noor, J. 2011. Metodologi Penelitian Skripsi, Tesis, Disertasi, dan Karya Ilmiah. Jakarta : Kencana Prenada Media Group.

Pemerintah Kabupaten Lamongan, 2019. Gambaran Umum Kabupaten Lamongan.

Primyastanto, M. 2011. Feasibility Study Usaha Perikanan (Sebagai Aplikasi Dari Teori Studi Kelayakan Usaha Perikanan. Malang : UB Press.

Sa'adah, W. 2018. Pengasapan Ikan Tawes Sebagai Upaya dalam Peningkatan Nilai Jual Produk dan Pendapatan Usaha di Kabupaten
Lamongan. Prosiding Seminar Nasional Agribisnis dan Pengembangan Ekonomi Perdesaan $V$. Program Studi Agribisnis Fakultas Pertanian Universitas Trunojoyo Madura. pp. 109-113.

Soekartawi, 2006. Analisis Usahatani. Jakarta : UI Press. 